\title{
Productivity, bromatological composition and economic benefits of using irrigation in the forage cactus under regulated deficit irrigation in a semiarid environment
}

\author{
George do Nascimento Araújo Júnior ${ }^{1}$ (D), Thieres George Freire da Silva1,* (D), Luciana Sandra Bastos \\ de Souza ${ }^{1}$ D, Marcondes de Sá Souza ${ }^{1}$ (D), Gherman Garcia Leal de Araújo² (iD, Magna Soelma Beserra \\ de Moura² (D), João Pedro Alves de Souza Santos ${ }^{1}$ (D), Alexandre Maniçoba da Rosa Ferraz Jardim ${ }^{1}$ (D), \\ Cleber Pereira Alves ${ }^{1}$ iD, Hygor Kristoph Muniz Nunes Alves ${ }^{1}$ \\ 1. Universidade Federal Rural de Pernambuco - Unidade Acadêmica de Serra Talhada - Laboratório de Agrometeorologia - Serra Talhada (PE), \\ Brazil. \\ 2. Empresa Brasileira de Pesquisa Agropecuária - Centro de Pesquisa Agropecuária do Trópico Semi-Árido - Laboratório de Agrometeorologia \\ - Petrolina (PE), Brazil.
}

Received:Sep. 2, 2020 | Accepted: Dec. 7,2020

Section Editor: Ivo Gonçalves

*Corresponding author: thieres.silva@ufrpe.br

How to cite: Araújo Júnior, G. N., Silva T. G. F., Souza L. S. B., Souza M. S., Araújo, G. G. L., Moura M. S. B., Santos J. P. A. S., Jardim, A. M. F. R., Alves C. P. and Alves H. K. M. N. (2021). Productivity, bromatological composition and economic benefits of using irrigation in the forage cactus under regulated deficit irrigation in a semiarid environment. Bragantia, 80, e1221. https://doi.org/10.1590/1678-4499.20200390

\begin{abstract}
The use of irrigation can improve the productivity and nutritional quality of the forage cactus in environments with a water deficit, resulting in profit to the producer. The productive performance, bromatological composition and economic benefits of using irrigation were investigated in this study with forage cactus clones regulated deficit irrigation (RDI). The study was conducted in an experimental design of randomised blocks, in a factorial scheme with subdivided plots. The plots consisted of water regimes based on the crop evapotranspiration (ETc) (rainfed, 40, 80 and 120\% ETc). The cactus clones ['Miúda' (MIU), 'Orelha de Elefante Mexicana' (OEM) and 'IPA Sertânia' (IPA)] comprised the subplots. The total number of cladodes per plant, the fresh and dry matter yields and the bromatological composition were evaluated. Economic viability was assessed using the net revenue and benefit to cost ratio (BCR). The irrigation depths did not increase the yield of the clones. The OEM clone showed 276 and 343\% greater fresh and dry matter production, respectively, when compared to the IPA clone; however, when compared with the MIU clone, it was $63 \%$, both on a fresh and dry matter production. The water regimes had no effect on the nutritional quality of the cactus. Only IPA showed no profit during the first cycle $(B C R<1)$. It can be concluded that planting one irrigated hectare with the OEM and MIU clones offer economic returns starting from the first production cycle (18 months).

Key words: Nopalea sp., Opuntia stricta sp., irrigation economic viability, water stress.
\end{abstract}

\section{INTRODUCTION}

The cactus (Nopalea spp. and Opuntia spp.) is a forage resource of great agricultural importance in various regions of the planet, especially in environments with a water deficit (Peixoto et al. 2018). Due to its crassulacean acidic metabolism, the species display high water use efficiency, which ensures that the seasonality of forage production throughout the year is reduced (Freire et al. 2018; Silva et al. 2015a).

Of all the areas in the world, the semiarid region of Brazil is where the cactus is most used as forage for animal feed. Among the more important clones are the 'Orelha de Elefante Mexicana' (Opuntia stricta (Haw.) Haw.), 'Miúda' (Nopalea cochenillifera (L.) Salm-Dyck) and 'IPA Sertânia' (Nopalea cochenillifera (L.) Salm-Dyck), all of which are resistant to the cochineal scale bug (Dactylopius opuntiae Cockerell, 1929, Hemiptera: Dactylopidae), the main pest of 
the crop. These species are usually grown under rain-fed conditions, as they are well-adapted to water deficit (Alves et al. 2017; Barbosa et al. 2018). However, critical water regimes can cause changes in the growth and development of the cactus, which affects the production and nutritional value of the forage, but depend on the type of clone (Silva et al. 2015a; Lima et al. 2018).

The use of irrigation in cultivating the cactus in semiarid environments has been reported by several authors (Lima et al. 2016; Morais et al. 2017). According to Lima et al. (2018), irrigation in a production system depends on the agroeconomic performance, which is based on productive response, net revenue and economic viability.

A controlled water deficit is a type of management that allows the minimal use of water, without necessarily compromising crop yield, but with a reduction in the costs of irrigation, energy and labour (Levidow et al. 2014; Berbel et al. 2018). Lima et al. (2015) found productivity of $30 \mathrm{mg} \cdot \mathrm{ha}^{-1} \cdot \mathrm{year}^{-1}$ dry biomass in Nopalea sp. under drip irrigation with saline water. Queiroz et al. (2015) saw no effects from irrigation depth on the productivity of fresh or dry biomass (131.6 and $8.18 \mathrm{mg} \cdot \mathrm{ha}^{-1}$ ) in O. stricta (Haw.) Haw. Neither studies evaluated the economic benefits of using irrigation.

The hypothesis tested in this study is that the use of regulated deficit irrigation (RDI) strategy, based on cactus evapotranspiration values, has no negative impact on the productivity or nutritional quality of the forage, resulting in profitability of the production system. The aim was to analyse the productivity, bromatological composition and economic benefits of using irrigation in forage cactus clones under different regulated deficit irrigation.

\section{MATERIAL AND METHODS}

\section{Study area}

The experiment was conducted at the International Reference Centre for Agrometeorological Studies of the Cactus and other Forage Plants, at the Serra Talhada Academic Unit of the Federal Rural University of Pernambuco (UFRPE - UAST), in Serra Talhada, Pernambuco, Brazil (7 $7^{\circ} 59^{\prime} \mathrm{S}, 38^{\circ} 15^{\prime} \mathrm{W}$ and $431 \mathrm{~m}$ ). According to the Köppen classification, the climate in the region is type BShw', with an average annual rainfall of $642 \mathrm{~mm} \cdot \mathrm{year}^{-1}$, average air temperature of $24.8{ }^{\circ} \mathrm{C}$, relative humidity of $62 \%$ and atmospheric demand greater than $1,800 \mathrm{~mm} \cdot$ year $^{-1}$ (Pereira et al. 2015; Silva et al. 2015b). The soil was classified as typic eutrophic Ta Haplic Cambisol. The chemical and physical properties of the soil are shown in Table 1.

Table 1. Chemical and physical attributes of soil cultivated with forage cactus clones under different water regimes ( $0 \%$ ETc - rainfed, $40 \%$ ETc and $80 \%$ ETc - regimes with regulated deficit irrigation; and $120 \%$ ETc - water regime greater than the crop requirement, where ETc is the crop evapotranspiration), in the district of Serra Talhada, Pernambuco, in the semiarid region of Brazil.

\begin{tabular}{|c|c|c|c|c|c|c|c|c|c|c|c|}
\hline \multirow{2}{*}{$\begin{array}{l}\text { Depth } \\
\text { (m) }\end{array}$} & \multirow{2}{*}{$\begin{array}{c}\mathrm{EC} \\
\mathrm{mS} \cdot \mathrm{cm}^{-1}\end{array}$} & \multirow{2}{*}{$\mathrm{pH}$} & C & OM & $\mathbf{P}$ & $\mathbf{K}$ & $\mathrm{Na}$ & $\mathrm{Ca}$ & Mg & \multirow{2}{*}{ CEC } & \multirow{2}{*}{$\begin{array}{l}\text { V } \\
\%\end{array}$} \\
\hline & & & $\mathbf{g} \cdot \mathbf{k g}^{-1}$ & $\mathbf{g} \cdot \mathbf{k g}^{-1}$ & $\mathrm{mg} \cdot \mathrm{dm}^{-3}$ & \multicolumn{4}{|c|}{ 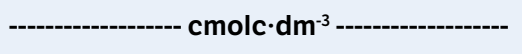 } & & \\
\hline $0.0-0.10$ & 0.87 & 6.9 & 5.8 & 10.0 & 78.1 & 1.3 & 0.04 & 4.0 & 1.6 & 7.4 & 94 \\
\hline $0.10-0.20$ & 0.52 & 6.7 & 4.8 & 8.3 & 66.5 & 0.7 & 0.03 & 4.5 & 2.2 & 8.2 & 91 \\
\hline \multirow{2}{*}{$\begin{array}{l}\text { Depth } \\
\text { (m) }\end{array}$} & \multicolumn{3}{|c|}{ Density $\left(\mathrm{g} \cdot \mathrm{dm}^{-3}\right)$} & \multirow{2}{*}{\multicolumn{3}{|c|}{ Total porosity (\%) }} & \multicolumn{5}{|c|}{ Particle size $\left(\mathrm{g} \cdot \mathrm{kg}^{-1}\right)$} \\
\hline & Soil & \multicolumn{2}{|c|}{ Particle } & & & & Total sand & \multicolumn{2}{|c|}{ Silt } & \multicolumn{2}{|c|}{ Clay } \\
\hline $0.0-0.10$ & 1.58 & \multicolumn{2}{|c|}{2.43} & \multicolumn{3}{|c|}{34.8} & 833 & \multicolumn{2}{|c|}{128} & \multicolumn{2}{|c|}{38} \\
\hline $0.10-0.20$ & 1.60 & \multicolumn{2}{|c|}{2.53} & \multicolumn{3}{|c|}{36.7} & 830.4 & \multicolumn{2}{|c|}{118.8} & \multicolumn{2}{|c|}{50.8} \\
\hline
\end{tabular}

EC - electrical conductivity; OM - organic matter; CEC - cation exchange capacity; $V$ - base saturation index 


\section{Implementation of the experiment, plant material and applied treatments}

The cactus crop was planted in the experimental area on January 6, 2016. Before planting, the soil was ploughed and furrowed and the cactus cladodes placed in the soil with $50 \%$ of their length buried. Up until the end of December 2016, the crop was grown under rainfed conditions and from January 2017, when the experimental period of the present study began, the different deficit irrigations were imposed until harvesting on June 30, 2018, a total of 567 days ( 18 months) (Fig. 1).

The forage cactus clones were arranged in a randomised block design, in a $4 \times 3$ factorial scheme with subdivided plots and four replications. The plots consisted of four deficit irrigations based on a percentage of the crop evapotranspiration (ETc) (rainfed, 40, 80 and 120\% ETc). The water regime of $0 \%$ ETc was considered the control, i.e., rainfed cultivation; $40 \% \mathrm{ETc}$ and $80 \% \mathrm{ETc}$, regulated deficit irrigations; and, $120 \% \mathrm{ETc}$, a water regime greater than the crop requirement. The ETc is calculated by multiplying reference evapotranspiration (ET0) by crop coefficient (kc). The daily ET0 was calculated using the Penman-Monteith equation (Allen et al. 1998), for which meteorological variables were monitored by means of an automatic station of the National Institute of Meteorology (named Serra Talhada, Pernambuco, Brazil and OMM code: A350), located $30 \mathrm{~m}$ from the experimental area. For the kc, values used were those recommended by Queiroz et al. (2016).

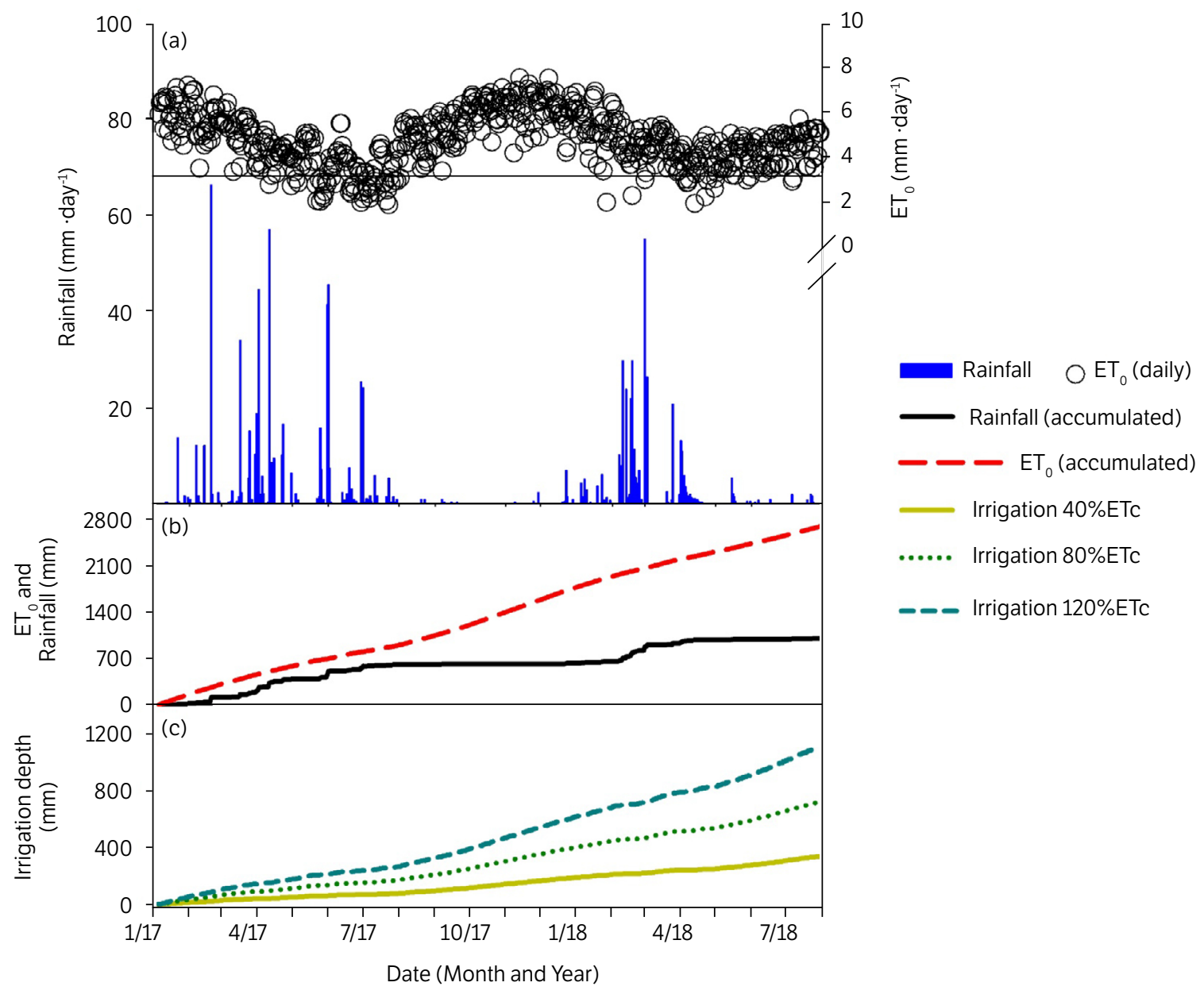

Figure 1. Rainfall, reference evapotranspiration (ETO) and applied irrigation depths ( $40 \%$ ETc and $80 \%$ ETc - regimes with regulated deficit irrigation; and $120 \% \mathrm{ETc}$ - water regime greater than the crop requirement, where ETc is the crop evapotranspiration) in the cultivation of forage cactus clones in the district of Serra Talhada, Pernambuco, in the semiarid region of Brazil. 
The subplots comprised three clones, Miúda [MIU, N. cochenillifera (L.) Salm-Dyck], Orelha de Elefante Mexicana [OEM, O.stricta (Haw.) Haw] and IPA Sertânia [IPA, N. cochenillifera (L.) Salm-Dyck], arranged in the field at a spacing of $1.0 \times 0.2 \mathrm{~m}$ (an initial density of 50,000 plants $\cdot \mathrm{ha}^{-1}$ ). Each plot was $60 \mathrm{~m}^{2}$ and consisted of four crop rows with 75 plants from each clone.

Irrigation was carried out three times a week using a drip system with a uniform water application of $93 \%$ and emitters spaced $0.20 \mathrm{~m}$ apart, at a flow rate of $2.25 \mathrm{~L} . \mathrm{h}^{-1}$ and pressure of $100 \mathrm{kPa}$. Irrigation was applied whenever the rainfall was less than the accumulated ETc between irrigations. The water came from an artesian well and had an electrical conductivity of $1.51 \mathrm{dS} . \mathrm{m}^{-1}$ with sodium and potassium concentrations of 168.66 and $28.17 \mathrm{mg} . \mathrm{L}^{-1}$, respectively.

The mean $\mathrm{ET}_{0}$ was equal to $4.72 \mathrm{~mm} \cdot$ day $^{-1}$ (Fig. 1a). In the treatments of 40,80 and $120 \% \mathrm{ETc}$, the irrigation depths during 567 days ( 18 months) accumulated 347,738 and 1,132 $\mathrm{mm}$ respectively, which, when added to the rainfall $(1,005 \mathrm{~mm})$, resulted in 1,352 (40\% ETc), 1,743 (80\% ETc) and 2,137 mm (120\% ETc). These values are equivalent to 647, $870,1,122$ and $1,376 \mathrm{~mm} \cdot$ year $^{-1}$. Treatment was also carried out throughout the period to control diseases and weeds. Chemical fertiliser was applied every three months using $50 \mathrm{~kg} \cdot \mathrm{ha}^{-1}$ formulation $14-00-08$ (NPK), as recommended by the Agronomic Institute of Pernambuco.

\section{Productivity of the forage cactus clones}

The productivity of the clones was determined at the time of harvest, on June 30,2018. The total number of cladodes was counted on one plant in each plot. When harvesting, only the basal cladode was left. The other cladodes were weighed to obtain the fresh weight of the plot. Two representative cladodes of a plant were chosen per plot and weighted to obtain the fresh weight. Then, the cladodes were sliced up, put into paper bags and placed in a forced air circulation oven at $55^{\circ} \mathrm{C}$ to constant weight (Silva and Queiroz 2005). The dry matter content of the cladodes was obtained from the ratio between the values for dry and fresh weight. fresh matter production (FMP, Mg.ha-1 ${ }^{-1}$ ) was estimated by extrapolating the mean fresh weight of one plant and the final plant density. For the production of dry matter (DMP, Mg.ha- ${ }^{-1}$ ), the dry matter content and the FMP were considered.

\section{Bromatological composition of the forage cactus clones}

The dry matter samples of the cladodes, oven-dried at $55^{\circ} \mathrm{C}$, were again dried in the oven at $105^{\circ} \mathrm{C}$ to obtain the final dry matter. The organic (OM) and mineral (MM) matters were obtained in an electric muffle furnace at $600{ }^{\circ} \mathrm{C}$; neutral (NDF) and acid (ADF) detergent fibre in an autoclave at $100^{\circ} \mathrm{C}$; crude protein (CP), in a nitrogen distiller using the Kjeldahl method; and ether extract (EE) and in-vitro dry matter digestibility (IVDDM) by following the procedures described in Association of Official Analytical Chemists (AOAC 1990). The total carbohydrates (TC) were determined by following the method of Sniffen et al. (1992).

\section{Economic analysis}

In order to analyse the economic benefits resulting from the use of regulated deficit irrigation strategy, a survey of the cost of the equipment was made (pipes, drip tapes, connections, motor-pump and filter set), in addition to the planting costs (preparation of the area, fertilisation, acquisition of the cladodes and labour), giving the total expenditure for setting up the project in an area of one hectare. The fixed costs for depreciation of the components of the irrigation system (CD) and of the interest on investment capital (IC) were calculated, in addition to the variable costs for electricity (EEC), labour (LC) and maintenance of the system components, as per Dantas et al. (2017) and Lima et al. (2018). Revenue was calculated based on selling the cactus for forage or planting, using the expressions: 


$$
\text { GRsf }=\text { Y.valueY }
$$

$$
\text { GRsc }=(\text { NP.TNC).valueC }
$$

where, $\mathrm{GR}_{\mathrm{sf}}=$ gross revenue resulting from selling the cactus for forage (US\$); $\mathrm{Y}=$ crop yield $\left(\mathrm{Mg}^{\circ} \mathrm{ha} \mathrm{a}^{-1}\right)$; valueY $=\mathrm{crop}$ yield value (US\$ $\cdot \mathrm{Mg}^{-1}$ ) considering US\$ 36.31 per $\mathrm{Mg} ; \mathrm{GR}_{\mathrm{sc}}=$ gross revenue resulting from sale of the cladodes for planting (US\$); $\mathrm{NP}=$ number of plants per hectare; TNC $=$ total number of cladodes (unit); and valueC $=$ value per cladode $\left(U S \$ \cdot u^{-1}\right.$ ), considering US\$ 0.073 for the OEM clone, US\$ 0.06 for the IPA clone and US\$ 0.036 for the MIU clone. Net revenues were calculated using the equations (Dantas et al. 2017; Lima et al. 2018):

$$
\begin{aligned}
& \text { NRsf }=\text { GRsf }- \text { TPC } \\
& \text { NRsc }=\text { GRsc }- \text { TPC }
\end{aligned}
$$

where, NRsf = net revenue resulting from selling the cactus for forage (US\$); TCP = total production costs (US\$); and $\mathrm{NRsc}=$ net revenue resulting from sale of the cladodes for planting (US\$). The BCR was calculated from the data for net revenue and total production costs (Dantas et al. 2017; Lima et al. 2018):

$$
\mathrm{BCR}=\mathrm{NR} / \mathrm{TPC}
$$

where, $\mathrm{BCR}=$ benefit to cost ratio (> 1 shows economic viability); $\mathrm{NR}=$ net revenue (US $\$$ ) and TPC $=$ total production costs (US\$).

\section{Statistical analysis}

The data for fresh and dry matter production, total number of cladodes and bromatological composition were submitted to tests of normality and homoscedasticity and analysis of variance. When significant, the mean values were compared using Tukey's test at 5\% probability. All statistical analysis was carried out using the R software (R Core Team 2018) and the graphics were prepared using the SigmaPlot 14.0 software.

\section{RESULTS}

There was no effect from the interaction or from the deficit irrigations on the productive performance of the forage cactus clones $(\mathrm{p}>0.05)$. There was an effect from the clones on the fresh and dry matter yield and on the total number of cladodes. The OEM clone showed 276 and $343 \%$ greater fresh and dry matter yield, respectively, when compared to the IPA clone. However, when compared with MIU clone it was 63\%, on a fresh and dry matter production. The MIU clone showed greater cladode emission $(\mathrm{p}<0.05)$, whereas, OEM and IPA clones did not differ from each other (Table 2).

For the bromatological composition of the forage cactus clones, the only effect of the clones was on the final dry matter content. The MIU and OEM clones showed higher levels than the IPA clone, although no significant difference was observed between OEM and IPA clones (Table 3). Therefore, the mean values of MM, OM, NDF, $\mathrm{ADF}, \mathrm{CP}, \mathrm{EE}, \mathrm{TC}$ and IVDDM for the forage cactus were 17.08, 82.9, 16.66, 3.83, 3.82, 0.82, 78.25 and 82.01\%, respectively (Table 3 ). 
Table 2. Productivity in forage cactus clones grown under different water regimes ( $0 \%$ ETc - rainfed, $40 \%$ ETc and $80 \%$ ETc - regimes with regulated deficit irrigation; and $120 \%$ ETc - water regime greater than the crop requirement, where ETc is the crop evapotranspiration), in the district of Serra Talhada, Pernambuco, in the semiarid region of Brazil.

\begin{tabular}{|c|c|c|c|c|c|c|c|}
\hline \multirow[b]{2}{*}{ Variable } & \multicolumn{3}{|c|}{ ANOVA [p-value] } & \multicolumn{3}{|c|}{ Tukey's test [Clones effect] } & \multirow[b]{2}{*}{ CV (\%) } \\
\hline & Clones (C) & $\begin{array}{c}\text { Deficit } \\
\text { irrigation (DI) }\end{array}$ & $\mathrm{C} \times \mathrm{DI}$ & MIU & OEM & IPA & \\
\hline TNC & $0.00^{* *}$ & $0.09^{\text {ns }}$ & $0.79^{\text {ns }}$ & $32 a$ & $13 b$ & $15 b$ & 34 \\
\hline Y.FM & $0.00^{* *}$ & $0.17^{\mathrm{ns}}$ & $0.78^{\text {ns }}$ & $191 b$ & $312 a$ & $83 c$ & 29 \\
\hline Y.DM & $0.00^{\star *}$ & $0.15^{\text {ns }}$ & $0.72^{\mathrm{ns}}$ & $19 b$ & $31 a$ & 7c & 29 \\
\hline
\end{tabular}

ANOVA: Analysis of variance; Mean values followed by the same letter on a line, do not differ by Tukey's test at 5\%; "** and ns: significant at 1 and $5 \%$ and not significant respectively; MIU - Miúda; OEM - Orelha de Elefante Mexicana; IPA - IPA Sertânia; TNC - Total number of cladodes (units); Y.FM - Fresh mass production (Mg.ha-1); Y.DM - Dry mass production (Mg.ha-1); WR - water regime; CV - Coefficient of variation.

Table 3. Bromatological composition of forage cactus clones under different water regimes ( $0 \%$ ETc - rainfed, $40 \%$ ETc and $80 \%$ ETc-regimes with regulated deficit irrigation; and $120 \%$ ETc - water regime greater than the crop requirement, where ETc is the crop evapotranspiration), in the district of Serra Talhada, Pernambuco, in the semiarid region of Brazil.

\begin{tabular}{|c|c|c|c|c|c|c|c|}
\hline \multirow[b]{2}{*}{ Variable } & \multicolumn{3}{|c|}{ ANOVA [p-value] } & \multicolumn{3}{|c|}{ Tukey's test [Clones effect] } & \multirow[b]{2}{*}{ CV (\%) } \\
\hline & Clones (C) & $\begin{array}{c}\text { Deficit } \\
\text { irrigation (DI) }\end{array}$ & $\mathrm{C} \times \mathrm{DI}$ & MIU & OEM & IPA & \\
\hline $\mathrm{DM}$ & $0.00^{\star *}$ & $0.66^{\mathrm{ns}}$ & $0.92^{\text {ns }}$ & $9.51 a$ & $8.65 a b$ & $7.65 b$ & 15.9 \\
\hline MM & $0.38^{\text {ns }}$ & $0.96^{\mathrm{ns}}$ & $0.99^{\text {ns }}$ & 15.8 & 15.97 & 19.49 & 38.1 \\
\hline $\mathrm{OM}$ & $0.95^{\text {ns }}$ & $0.99^{\text {ns }}$ & $1.00^{\text {ns }}$ & 84.19 & 84.02 & 80.5 & 36.7 \\
\hline NDF & $0.93^{\text {ns }}$ & $0.47^{\mathrm{ns}}$ & $0.78^{\text {ns }}$ & 16.68 & 16.16 & 17.14 & 42.1 \\
\hline ADF & $0.21^{\text {ns }}$ & $0.54^{\mathrm{ns}}$ & $0.17^{\text {ns }}$ & 4.57 & 3.71 & 3.2 & 43.9 \\
\hline $\mathrm{CP}$ & $0.57^{\mathrm{ns}}$ & $0.89^{\text {ns }}$ & $0.71^{\mathrm{ns}}$ & 4.21 & 3.58 & 3.67 & 36.3 \\
\hline EE & $0.13^{\text {ns }}$ & $0.76^{\mathrm{ns}}$ & $0.40^{\text {ns }}$ & 0.64 & 0.8 & 1.02 & 41.2 \\
\hline $\mathrm{TC}$ & $0.57^{\mathrm{ns}}$ & $0.98^{\text {ns }}$ & $0.99^{\text {ns }}$ & 78.98 & 79.76 & 76.02 & 10.5 \\
\hline IVDDM & $0.99^{\text {ns }}$ & $0.96^{\text {ns }}$ & $0.99^{\text {ns }}$ & 81.96 & 82.66 & 81.41 & 35.9 \\
\hline
\end{tabular}

ANOVA: Analysis of variance; Mean values followed by the same letter on a line, do not differ by Tukey’s test at $5 \%$; "* , and ns: significant at $1 \%$ and $5 \%$, and not significant respectively; MIU - Miúda; OEM - Orelha de Elefante Mexicana; IPA - IPA Sertânia; DM - final dry matter; MM - mineral matter; OM - organic matter; NDF - neutral detergent fibre; FDA - acid detergent fibre; CP - crude protein; EE - ether extract; TC- total carbohydrates; IVDDM - in vitro dry matter digestibility; $\mathrm{CV}$ - Coefficient of variation.

The total cost of producing one hectare of irrigated cactus was US $\$ 6,452,64 \%$ higher than the cost of rainfed cultivation (US\$ 4,130) (Table 4). The highest fixed costs are associated with setting up the crop (72\%) and the impulse line of the irrigation pumping system (17\%). As variable costs, the interest on invested capital, depreciation of the components of the irrigation system and labour costs correspond to 40,30 and $18 \%$, respectively (Fig. 2).

Table 4. Fixed and variable costs, in US\$.ha ${ }^{-1}$, in setting up rainfed and irrigated crops of forage cactus, in the district of Serra Talhada, Pernambuco, in the semiarid region of Brazil.

\begin{tabular}{ccccc}
\hline Costs & 0\% ETc Rainfed & 40\% ETc Irrigated & $\mathbf{8 0 \%}$ ETc Irrigated & \multicolumn{1}{c}{ 120\% ETc Irrigated } \\
\hline Fixed & 3,893 & 5,476 & 5,476 & 5,476 \\
Variable & 237 & 967 & 977 & 985 \\
\hline Total & 4,130 & 6,443 & 6,453 & 6,461
\end{tabular}

0\% ETc - rainfed water regime, 40\% ETc and $80 \%$ ETc - regimes with regulated deficit irrigation; $120 \%$ ETc - water regime greater than the crop requirement.

Economic profitability varied according to the end use of the harvested product. For sale as fodder, the OEM clone showed a higher net revenue (NR) and benefit to cost ratio (BCR) in all the irrigated systems (Fig. 3a, 3c). The average NR was US\$17,322, with a BCR of 3.12. The MIU and IPA clones obtained an NR of US\$ 8,046 and 3,223 with a BCR of 1.43 and 0.61 , respectively. When selling the cladodes for planting (Fig. 3b, 3d), the highest revenues were generated by 
MIU (US\$ 19,843), followed by OEM (US\$ 12,170) and IPA (US\$ 4,195). The respective BCR ratios were 3.77, 2.22 and 0.85 , indicating economic viability in the first year of production for the irrigated crops of the MIU and OEM clones.

(a)

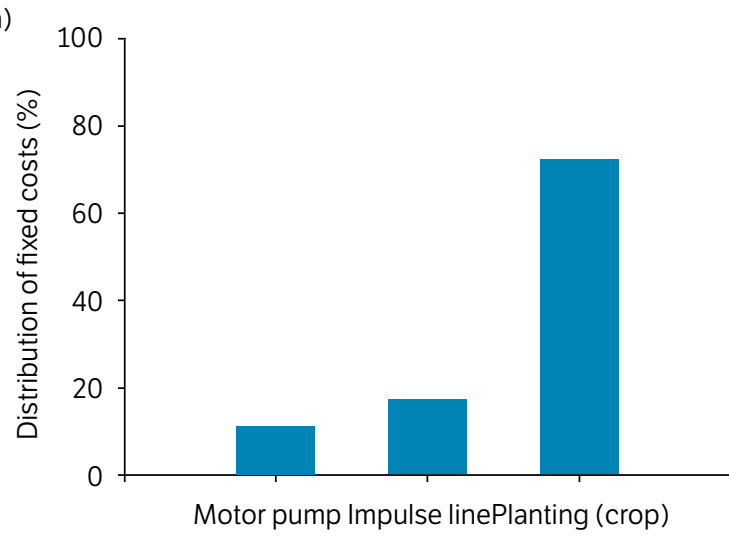

(b)

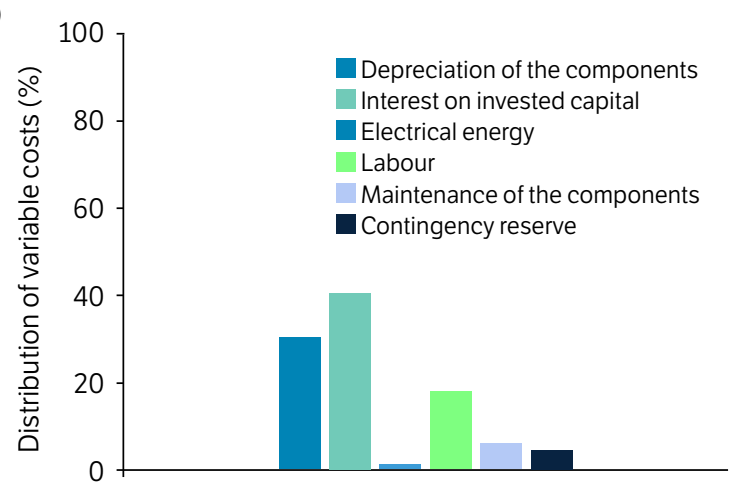

Figure 2. Participation, as a percentage, of the components of fixed (a) and variable costs (b) in setting up irrigated crops of forage cactus, in the district of Serra Talhada, Pernambuco, in the semiarid region of Brazil.
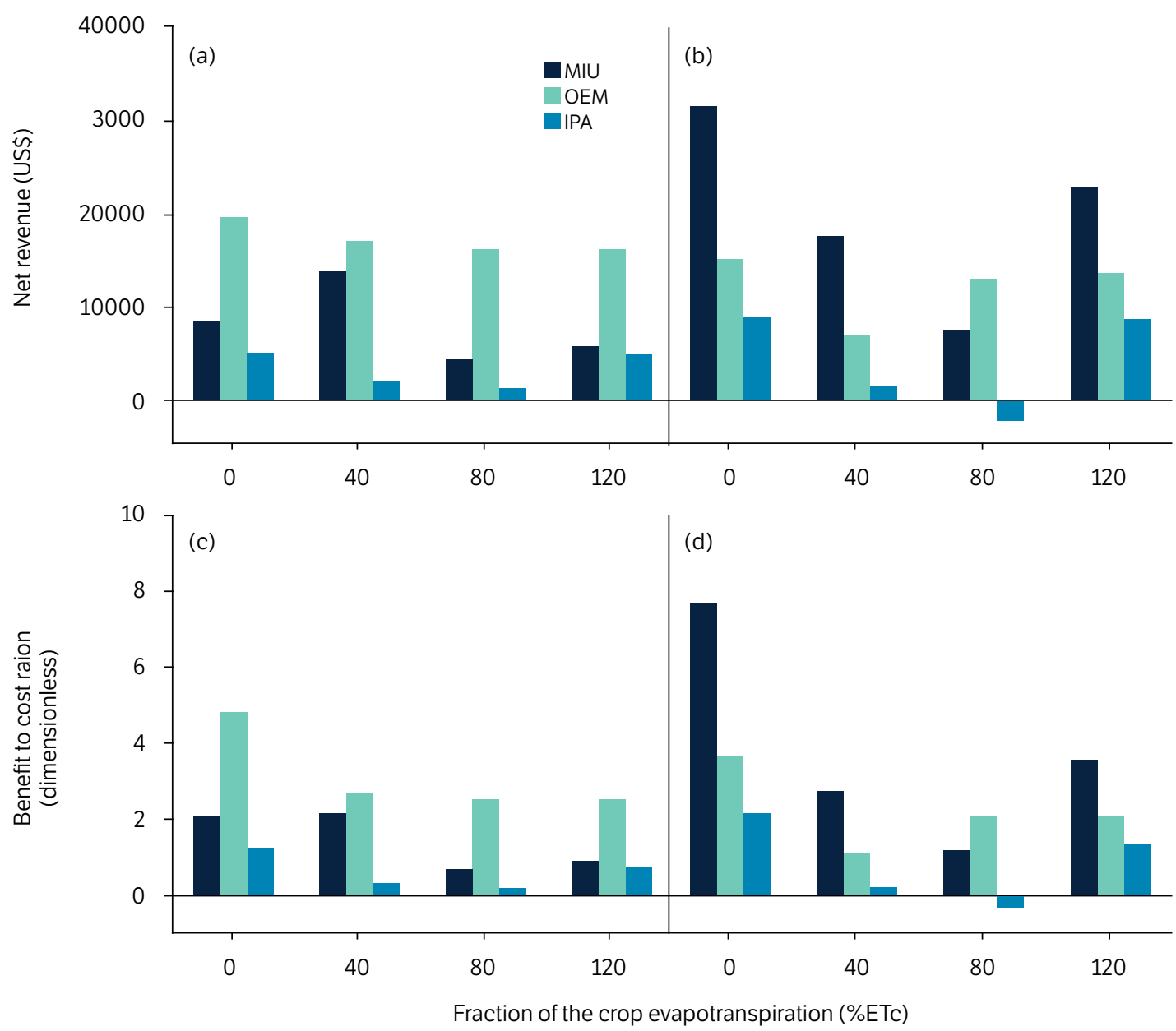

Figure 3. Net sales revenue as fodder (a) and for planting (b) and cost / benefit ratio of the sale as fodder (c) and for planting (d) in clones of the forage cactus under different water regimes (0\% ETc - rainfed, $40 \%$ ETc and $80 \%$ ETc - regimes with regulated deficit irrigation; and $120 \%$ ETc - water regime greater than the crop requirement, where ETc is the crop evapotranspiration), in the district of Serra Talhada, Pernambuco, in the semiarid region of Brazil. 


\section{DISCUSSION}

The absence of any effect from the deficit irrigations on the productive performance of the cactus is associated with the rainfall regime (amount and distribution) throughout the experimental period (1,005 $\mathrm{mm}$ in 18 months, equivalent to $647 \mathrm{~mm} \cdot$ year $^{-1}$ ), which was close to the climatological normal of the region $\left(642 \mathrm{~mm} \cdot\right.$ year $\left.^{-1}\right)$. Other studies have also found no influence from irrigation on productivity in species of Opuntia sp. (Queiroz et al. 2015; Flores-Hernández et al. 2004). Flores-Hernández et al. (2004) mention that increasing the irrigation depth from 760 to $1380 \mathrm{~mm} \cdot y e a r^{-1}$ did not increase the yield in species of Opuntia. With depths of 976 to 1,202 mm.year-1, Queiroz et al. (2015) also found no effects on O. stricta.

Despite adapting to arid and semiarid environments (Arba et al. 2018; Liguori et al. 2013), the cactus is strongly influenced by environmental conditions (Silva et al. 2015 a). According to Nobel (2001), regions with an annual rainfall between 400 and $800 \mathrm{~mm}$ and an average air temperature between 16 and $2{ }^{\circ} \mathrm{C}$, favour rainfed cultivation for the cactus. Silva et al. (2017) state that locations where the rainfall is greater than $493 \mathrm{~mm} \cdot$ year $^{-1}$ with at least $55 \mathrm{~mm} \cdot \mathrm{month}^{-1}$ over seven months require no irrigation.

In the present study, the productive performance of the forage cactus varied by clone only. The higher total number of cladodes for MIU was expected, as it is an intrinsic morphological characteristic of this clone (Silva et al. 2017). Although it belongs to the same genus as MIU, IPA had the lowest TNC, showing no difference to the OEM clone. The distribution, size and number of cladodes determine the architecture of the plant, affecting the photosynthetic capacity of the crop and thereby its productivity (Pinheiro et al. 2014; Barbosa et al. 2018).

The OEM clone showed greater fresh and dry matter yields compared to MIU and IPA. The high productivity of Opuntia is related to its water use efficiency (Morais et al. 2017; García-Nava et al. 2015) and higher rate of forage accumulation (Rocha et al. 2017), in addition to high values for cladode area, which enables a large accumulation of water and a greater photosynthetic area (Silva et al. 2015 a).

The mean value for fresh weight yield achieved by the OEM clone (312 Mg.ha-1) was higher than that found by Nadaf

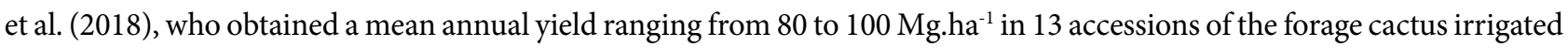
with saline water. However, the productivity achieved by the clones in the present study was lower than that reported by Rocha et al. (2017), where the OEM, MIU and IPA cultivars, fertigated with nonsaline water for over 16 months, obtained yields greater than 700, 300 and $400 \mathrm{Mg} \mathrm{FM} \cdot \mathrm{ha}^{-1}$, respectively.

The forage cactus has a low tolerance to salinity, which can affect its productive performance (Freire et al. 2018). IPA Sertânia had the lowest yield and this can be explained by the high mortality rate of the plants when irrigated (68\%). Miúda also showed high mortality (50\%), while in the mortality of the OEM clone was $28 \%$. Silva et al. (2015a) affirm that clones of genus Nopalea have greater difficulty in becoming established when compared to the species of genus Opuntia.

The bromatological composition of the forage cactus clones was not affected by the imposed deficit irrigations. The final dry matter was the only variable of forage quality that showed a significant difference between clones. There are many factors that affect the chemical composition of the forage cactus, including climate conditions, time of cultivation, age, variety, species and order of cladodes (Alves et al. 2017; Hernández-Urbiola et al. 2011). The values found for final dry matter in the MIU (9.51\%), OEM (8.65\%) and IPA (7.65\% DM) clones are considered low when compared to those reported in other studies, but conducted under rainfed conditions (Piños-Rodrigues et al. 2010). Under irrigated conditions, the cactus prioritises water accumulation in the cladodes, which reduces the accumulation of dry matter (Queiroz et al. 2015; Pereira et al. 2017).

The use of irrigation in the forage cactus should be determined with caution, since in places where the rainfall and air temperature meet the requirements of the cactus, the practice can be dispensed, if not the production system becomes costly (Lima et al. 2018). Under conditions with no water restriction, the temperature has a greater effect on the growth dynamics of these plants (Scalise et al. 2016); in very hot locations, the use of irrigation may be necessary to compensate for the excessive loss of water to the atmosphere (Lima et al. 2016).

The first investments in setting up a hectare of irrigated forage cactus involves preparing the soil, acquiring the cladodes for planting, hiring labour and purchasing and assembling the irrigation system. The latter components increase the setup costs of the cactus plantation (US\$ 6,453) compared to rainfed cultivation (US\$4,130). During the production cycle, the 
total value for fixed and variable costs and the expenses (Table 5), resulting from including the irrigation system varied between the different deficit irrigations of $40 \%$ ETc (US\$ 6,443) and 120\% ETc (US\$ 6,461) due to the cost of energy.

The present study showed that profitability varied according to the end use of the product. When the cladodes were destined for sale as animal feed, the OEM clone showed greater profitability under all the deficit irrigations, with an average NR of US\$17,323 (Fig. 3a) and an average BCR of 3.12 (Fig. 3c), showing that revenue was higher than the cost of production, i.e., cultivating the OEM clone, when destined for animal feed, offers an economic return to the producer of US\$3,12 for each US\$ 1,00 invested, starting from the first production cycle of the crop (18 months). There was a tendency for the NR and BCR to decrease as the irrigation depth increased. Similar results were obtained by Lima et al. (2018) when studying the productive and economic benefits of growing the cactus in a monocropped system or intercropped with sorghum and submitted to different irrigation depths.

For the MIU and IPA clones, the revenue generated when selling for animal feed was equal to US\$ 8,046 and 3,224 with a BCR of 1.43 and 0.61 respectively, showing that growing the IPA clone to be sold only for forage offers no economic return to the producer during the first production cycle (18 months), i.e., the revenue is lower than the setup cost $(B C R<1)$, which leads to the need for successive cycles to amortise the initial investment (Dantas et al. 2017; Lima et al. 2018).

When the forage cactus was destined to be sold for planting, the MIU clone was more profitable (US\$19,843) (Fig. 3b), with a higher BCR (3.77) (Fig. 3d). This is a result of the greater number of cladodes presented by the MIU when compared to the other clones (Table 4). For the OEM and IPA clones, the generated revenue was equal to US $\$ 12,170$ and 4,195 with a BCR of 2.22 and 0.85 , respectively. Just as seen in the sale for animal feed, growing the IPA clone for planting showed no economic profit during the first 18 months of cultivation $(\mathrm{BCR}<1)$. The high mortality rate of this clone during the experiment overextended the complete amortisation of the investment. The high BCR value under rainfed conditions (Figs. $3 \mathrm{c}$ and $3 \mathrm{~d}$ ) can be explained by the productive performance, which was similar to that of the irrigated crops, and to the cost of setting up the area, which was $64 \%$ lower than when irrigated (Table 4 ).

\section{CONCLUSION}

This study evaluated the yield, chemical composition and economic benefits of using irrigation in forage cactus clones under a controlled water deficit. The deficit irrigations did not promote any productive increase in the forage cactus clones, due to the rainfall depth over the experimental period (equivalent to $647 \mathrm{~mm} \cdot \mathrm{year}^{-1}$ ). However, the yields obtained in the present study are higher than those reported in other studies of crops under rainfed conditions. The 'Orelha de Elefante Mexicana' clone, of the genus Opuntia, showed better productive performance than the 'Miúda' and 'IPA Sertânia' clones did, both of genus Nopalea. The nutritional quality of the clones was not changed by the imposed deficit irrigations. The use of irrigation in the forage cactus should be determined based on local rainfall and thermal regimes, on the clone, and on the end use of the cladodes. Planting one irrigated hectare with the 'Orelha de Elefante Mexicana' and 'Miúda' clones offer economic returns, starting from the first production cycle (18 months), when the cladodes are destined to be sold for animal feed or for planting. The present study recommends further research into assessing water management in regions or during years of lower rainfall $\left(<647 \mathrm{~mm} \cdot\right.$ year $\left.^{-1}\right)$, where other levels of controlled water deficit, and different irrigation frequencies, planting times and cutting intensities (every 6, 9, 12, 15 and 18 months) might also be tested.

\section{AUTHORS' CONTRIBUTION}

Conceptualization: Silva T.G.F., Souza L.S.B. and Araújo, G.G.L.; Methodology: Silva T.G.F. and Araújo Júnior, G.N.; Investigation, Araújo Júnior, G.N., Souza M.S., Jardim, A.M.F.R., Alves C.P., Santos J.P.A.S. and Alves H.K.M.N; Writing - Original Draft: Araújo Júnior, G.N., Silva T.G.F. and Souza L.S.B.; Writing - Review and Editing: Silva T.G.F. and Moura M.S.B.; Funding Acquisition: Silva T.G.F.; Resources: Silva T.G.F., Moura M.S.B. and Araújo, G.G.L.; Supervision: Silva T.G.F.. 


\section{DATA AVAILABILITY STATEMENT}

Data sharing is not applicable

\section{FUNDING}

Fundação de Amparo à Ciência e Tecnologia do Estado de Pernambuco

https://doi.org/10.13039/501100006162

Grants No: APQ-0215-5.01/10 and APQ-1159-1.07/14)

Conselho Nacional de Desenvolvimento Científico e Tecnológico

https://doi.org/10.13039/501100003593

Grant Nos:

475279/2010-7, 476372/2012-7, 305286/2015-3, 309421/2018-7, and 152251/2018-9

Coordenação de Aperfeiçoamento de Pessoal de Nível Superior

https://doi.org/10.13039/501100002322

Finance Code 001

\section{ACKNOWLEDGMENTS}

The authors would like to thank to the members of the Agrometeorology Group in the Brazilian Semiarid.

\section{REFERENCES}

Allen, R. G., Pereira, L. S., Raes, D. and Smith, M. (1998). Crop evapotranspiration - Guidelines for computing crop requirements - FAO Irrigation and Drainage Paper 56. Rome: FAO. [Accessed Dec. 21, 2018]. Available at: https://www.scscourt.org/complexcivil/105CV049053/ volume3/172618e_5xAGWAx8.pdf

Alves, F. A. L. andrade, A. P., Bruno, R. L. A., Santos, D. C., Magalhães, A. L. R. and Silva, D. S. (2017). Chemical and Nutritional Variability of Cactus Pear Cladodes, Genera Opuntia and Nopalea. American Journal of Food Technology, 12, 25-34. https://doi.org/10.3923/ ajft.2017.25.34

[AOAC] Association of Official Analytical Chemists. (1990). Official methods of analysis of the association of official analytical chemists, 15th ed, Association of Official Analytical Chemists. Washington, DC.

Arba, M., Falisse, A., Choukr-Allah, R. and Sindic, M. (2018). Effect of irrigation at critical stages on the phenology of flowering and fruiting of the cactus Opuntia spp. Brazilian Journal of Biology, 78, 653-660. https://doi.org/10.1590/1519-6984.170086

Barbosa, M. L., Silva, T. G. F., Zolnier, S., Silva, S. M. S. and Steidle Neto, A. J. (2018). The influence of cladode morphology on the canopy formation of forage cactus plants. Revista Caatinga, 31, 180-190. https://doi.org/10.1590/1983-21252018v31n121rc

Berbel, J., Gutierrez-Marín, C. and Expósito, A. (2018). Impacts of irrigation efficiency improvement on water use, water consumption and response to water price at field level. Agricultural Water Management, 203, 423-429. https://doi.org/10.1016/j.agwat.2018.02.026 
Dantas, S. F. A., Lima, G. F. C. and Mota, E. P. (2017). Viabilidade econômica da produção de palma forrageira irrigada e adensada no semiárido Potiguar. Revista iPecege, 3, 59-74. https://doi.org/10.22167/r.ipecege.2017.1.59

Flores-Hernández, A., Orona-Castillo, I., Murillo-Amador, B., García-Hernández, J. L. and Troyo-Dieguez, E. (2004). Yield and physiological traits of prickly pear cactus 'nopal' (Opuntia spp.) cultivars under drip irrigation. Agricultural Water Management, 70, 97-107. https://doi. org/10.1016/j.agwat.2004.06.002

Freire, J. L., Santos, M. V. F., Dubeux Júnior, J. C. B., Bezerra Neto, E., Lira, M. A., Cunha, M. V., Santos, D. C., Amorim, S. O. and Mello, A. C. L. (2018). Growth of cactus pear cv. Miúda under different salinity levels and irrigation frequencies. Anais da Academia Brasileira de Ciências, 90, 3893-3900. https://doi.org/10.1590/0001-3765201820171033

García-Nava, F., Peña-Valdivia, C. B., Trejo, C., García-Nava, R., Reyes-Agüero, J. A. and Rivera, J. R. A. (2015). Biophysical and physiological characteristics of nopalitos (Opuntia spp., Cactaceae) as influenced by domestication. Genetic Resources and Crop Evolution, 62, 927938. https://doi.org/10.1007/s10722-014-0201-7

Hernández-Urbiola, M. I., Pérez-Torrero, E. and Rodríguez-García, M. E. (2011). Chemical Analysis of Nutritional Content of Prickly Pads (Opuntia ficus indica) at Varied Ages in an Organic Harvest. International Journal of Environmental Research and Public Health, 8, 12871295. https://doi.org/10.3390/ijerph8051287

Levidow, L., Zaccaria, D., Maia, R., Vivas, E., Todorovic, M. and Scardigno, A. (2014). Improving water-efficient irrigation: Prospects and difficulties of innovative practices. Agricultural Water Management, 146, 84-94. https://doi.org/10.1016/j.agwat.2014.07.012

Liguori, G., Inglese, G., Pernice, F., Sortino, G. and Inglese, P. (2013). CO2 uptake of Opuntia ficus-indica (L.) Mill. whole trees and single cladodes, in relation to plant water status and cladode age. Italian Journal of Agronomy, 8, 14-20. https://doi.org/10.4081/ija.2013.e3

Lima, G. F. C., Rêgo, M. M. T., Aguiar, E. M., Silva, J. G. M., Dantas, F. D. G., Guedes, F. X. and Lôbo, R. N. B. (2015). Effect of different cutting intensities on morphological characteristics and productivity of irrigated Nopalea forage cactus. Acta Horticuturae, 1067, 253258. https://doi.org/10.17660/ActaHortic.2015.1067.35

Lima, G. F. C., Rêgo, M. M. T., Dantas, F. D. G., Lôbo, R. N. B., Silva, J. G. M. and Aguiar, E. M. (2016). Morphological characteristics and forage productivity of irrigated cactus pear under different cutting intensities. Revista Caatinga, 29, 481-488. https://doi. org/10.1590/1983-21252016v29n226rc

Lima, L. R., Silva, T. G. F., Pereira, P. C., Morais, J. E. F. and Assis, M. C. S. (2018). Productive-economic benefit of forage cactus-sorghum intercropping systems irrigated with saline water. Revista Caatinga, 31, 191-201. https://doi.org/10.1590/1983-21252018v31n122rc

Morais, J. E. F., Silva, T. G. F., Queiroz, M. G., Araujo, G. G. L., Moura, M. S. B. and Araújo Júnior, G. N. (2017). Hydrodynamic changes of the soil-cactus interface, effective actual evapotranspiration and its water efficiency under irrigation. Revista Brasileira de Engenharia Agrícola e Ambiental, 21, 273-278. https://doi.org/10.1590/1807-1929/agriambi.v21n4p273-278

Nadaf, S. K., Al-Farsi, S. M., Al-Hinai, S. A., Al-Hinai, A. S., Al-Harthy, A. A. S., Al-Khamisi S. A. and Al-Bakri, A. N. (2018). Potential of forage cactus pear accessions under saline water irrigation in arid areas. Journal of the Professional Association for Cactus Development, 20, 68-81.

Nobel, P. S. (2001). Biologia ambiental. In G. Barbera, P. Inglese, and E. Pimienta-Barros (Eds.). Agroecologia, cultivo e usos da palma forrageira (p. 36-48). João Pessoa: FAO.

Peixoto, M. J. A., Carneiro, M. S. S., Amorim, D. S., Edvan, R. L., Pereira, E. S. and Costa, M. R. G. F. (2018). Características agronômicas e composição química da palma forrageira em função de diferentes sistemas de plantio. Archivos de Zootecnia, 67, 35-39. https://doi. org/10.21071/az.v67i257.3489

Pereira, P. C., Silva, T. G. F., Zolnier, S., Morais, J. E. F. and Santos, D. C. (2015). Morfogênese da Palma Forrageira Irrigada por Gotejamento. Revista Caatinga, 28, 184-195. https://doi.org/10.1590/1983-21252015v28n321rc 
Pereira, P. C., Silva, T. G. F., Zolnier, S., Silva, S. M. S. and Silva, M. J. (2017). Water balance in soil cultivated with forage cactus clones under irrigation. Revista Caatinga, 30, 776-785. https://doi.org/10.1590/1983-21252017v30n326rc

Pinheiro, K. M., Silva, T. G. F., Carvalho, H. F. S., Santos, J. E. O., Morais, J. E. F., Zonier, S. and Santos, D. C. (2014). Correlações do índice de área do cladódio com características morfogênicas e produtivas da palma forrageira. Pesquisa Agropecuária Brasileira, $49,939-947$. https://doi.org/10.1590/S0100-204X2014001200004

Piños-Rodrigues, J. M., Velázquez, J. C., Gonzáles, S. S., Aguirre, J. R., García, J. C., Álvares, G. and Jasso, Y. (2010). Effects of cladode age on biomass yield and nutritional value of intensively produced spineless cactus for ruminants. South African Journal of Animal Science, 40, 245-250. https://doi.org/10.4314/sajas.v40i3.14

Queiroz, M. G., Silva, T. G. F., Zolnier, S., Silva, S. M. S., Lima, L. R. and Alves, J. O. (2015). Características morfofisiológicas e produtividade da palma forrageira em diferentes lâminas de irrigação. Revista Brasileira de Engenharia Agrícola e Ambiental, 19, 931-938. https://doi. org/10.1590/1807-1929/agriambi.v19n10p931-938

Queiroz, M. G., Silva, T. G. F., Zolnier, S., Silva, S. M. S., Souza, C. A. A. and Carvalho, H. F. S. (2016). Relações hídrico-econômicas da palma forrageira cultivada em ambiente semiárido. Irriga, 1, 141-154. https://doi.org/10.15809/irriga.2016v1n01p141-154

R Core Team. (2018). A language and environment for statistical computing. Vienna: R Foundation for Statistical Computing. [Accessed Dec. 12, 2018]. Available at: https://www.R-project.org/.

Rocha, R. S., Voltolini, T. V. and Gava, C. A. T. (2017). Características produtivas e estruturais de genótipos de palma forrageira irrigada em diferentes intervalos de corte. Archivos de Zootecnia. 66, 255, 365-373. https://doi.org/10.21071/az.v66i255.2512

Scalise, A., Morandi, B., Inglese, P. and Lo Bianco, R. (2016). Cladode growth dynamics in Opuntia fícus-indica under drought. Environmental and Experimental Botany, 122, 158-167. https://doi.org/10.1016/j.envexpbot.2015.10.003

Silva, D. J. and Queiroz, A. C. (2005). Food analysis: chemical and biological methods. Minas Gerais: UFV.

Silva, T. G. F., Araújo Primo, J. T., Morais, J. E. F., Diniz, W. J. S., Souza, C. A. A. and Silva, M. C. (2015 a). Growth and productivity of cactus forage clones in semiarid and relationship with meteorological variables. Revista Caatinga, 28, 10-18. https://doi.org/10.1590/ S0100-204X2015000700001

Silva, T. G. F., Araújo Primo, J. T., Moura, M. S. B., Silva, S. M. S., Morais, J. E. F., Pereira, P. C. and Souza, C. A. A. (2015 b). Soil water dynamics and evapotranspiration of forage cactus clones under rainfed conditions. Pesquisa Agropecuária Brasileira, 50, 515-525. https://doi.org/10.1590/S0100-204X2015000700001

Silva, T. G. F., Araújo, G. G. L., Moura, M. S. B. and Souza, L. S. B. (2017). Agrometeorological research on forage cactus and its advances in Brazil. Amazonian Journal of Plant Research, 2, 45-68. https://doi.org/10.26545/b00006x

Sniffen, C. J., O'Connor, J. D., Van Soest, P. J., Fox, D. G. and Russell, J. B. (1992). A net carbohydrate and protein system for evaluating cattle diets: II. Carbohydrate and protein availability. Journal of Animal Science, 70, 3562-3577. https://doi.org/10.2527/1992.70113562x 